\title{
ETIKA ISLAM DALAM RANAH POLITIK: Respons dan Tinjauan Kritis Nahdlatul Ulama dan Muhammadiyah Provinsi Jambi terhadap Penyelenggaraan Pilkada Langsung (2005-2015)
}

\author{
Maulana Yusuf, Bahrul Ulum, M. Rusydi, M. Ishak \\ Fakultas Syariah UIN Sulthan Thaha Saifuddin \\ Jl. Lintas Ma. Bulian KM. 16 Simp. Sei Duren Jambi Luar Kota Muaro Jambi, 361361 \\ e-mail: irul70@yahoo.com
}

\begin{abstract}
Abstrak: Tulisan ini menelisik dampak Pilkada dan evaluasi kritis NU dan Muhammadiyah Jambi terhadap Pilkada langsung (2005-2015). Artikel ini mengajukan temuan bahwa Pilkada langsung telah menimbulkan dampak negatif bagi masyarakat, karena itu NU dan Muhammadiyah memandang penting untuk meninjau dan memberikan catatan kritis. Pertama, penyelenggara Pilkada harus objektif, amanah, adil, dan transparan. Kedua, masyarakat pemilih harus menggunakan hak pilihnya secara bertanggung jawab dan menghindari money politic. Ketiga, calon kepala daerah harus bersaing secara sehat, dan bersikap ksatria, siap kalah dan menang. Keempat, semua pihak dapat menghindari adanya black campaign, dan pembunuhan karakter pada pihak pesaing. Kelima, semua pihak harus mengikuti aturan-aturan Pilkada secara konsisten dan senantiasa menempatkan nilai-nilai agama dan moral masyarakat menjadi pedoman dan penuntun.
\end{abstract}

\begin{abstract}
Islamic Ethics in the Realm of Politics: Response and Critical Review of Nahdlatul Ulama and Muhammadiyah of Jambi Province Against the Implementation of Direct Elections (2005-2015). This paper reviews the impacts of election and the critical evaluations of NU and Muhammadiyah of Jambi against the direct elections during 2005-2015. The research found that the direct elections have negative impact on the people. Therefore, the NU and Muhammadiyah have considered to review and to provide critical notes; (i) The organizers of the elections must be objective, trustworthy, fair, and transparent. (ii) Voters should use their rights responsibly and avoid money politics, (iii) The candidates of the regional leaders must compete fairly, and be ready and gentleman whether they lose or win, (iv) All parties must avoid black campaign and character assassination to other competitors, (v) All parties must follow the rules of the election consistently and put religious (Islamic) values and public norms as guidance.
\end{abstract}

Kata Kunci: Indonesia, Jambi, Melayu, NU, Muhammadiyah, etika, politik 


\section{Pendahuluan}

Pemilihan umum kepala daerah (Pilkada) secara langsung yang telah berlangsung sejak tahun 2005, didasarkan pada ketentuan Undang-undang No. 32 Tahun 2004 dengan berlandaskan pada ketentuan Pasal 18 ayat (4) UUD 1945. Pilkada langsung dimaksudkan selain agar rakyat dapat menentukan sendiri pemimpin di daerahnya, diharapkan terjalinnya hubungan yang erat antara kepala daerah dengan rakyatnya. Namun Pemilu sebagai pintu masuk di ranah politik praktis, masih menjadi cita-cita yang jauh dari realitas. Prinsip demokrasi yang benar belum dipahami dan dipraktikkan oleh para politisi, sehingga kran demokrasi yang terbuka lebar kini menjadi kian absurd. ${ }^{1}$

Pilkada langsung selain menyemai tumbuh suburnya politik uang, juga melegitimasi praktik-praktik di masyarakat yang justru menodai semangat demokrasi, serta menciderai nilai-nilai agama dan moral. Realitas di lapangan membuktikan terjadi dialektika dan benturan kepentingan yang menyumbat proses demokrasi, karena itu tidak keliru jika ada pendapat yang mengatakan, terkadang demokrasi itu mati, justru melalui proses-proses yang tidak demokratis. $^{2}$

Memang, tidak semua fenomena ini menghadirkan praktik yang buruk karena adanya

${ }^{1}$ Ali Martin, "Quo Vadis Transisi Demokrasi: Arah Demokratisasi Indonesia di Tengah Demokrasi Pasar," dalam Spektrum, Vol. 7, No. 1 (Januari 2010), h. 10.

${ }^{2}$ Sidney Jones, Sisi Gelap Demokrasi Kekerasan Masyarakat Madani di Indonesia (Jakarta: Paramadina, 2015), h. 103. Pemahaman terhadap demokrasi juga terdistorsi oleh pemahaman yang hanya terbatas pada dimensi prosedural-elektoral, dan ini dapat menimbulkan persoalan serius terhadap penguatan demokrasi lokal di Indonesia. Lihat, Rudi Salam Sinaga, "Implikasi Distorsi Demokrasi Pada Pemilukada terhadap Penguatan Demokrasi Lokal," dalam Perspektif, Vol. 5. No. 1 (April 2012), h. 47. Namun mesti dipahami bahwa pada intinya demokrasi adalah suatu bentuk pemerintahan yang berdaulat di mana pemerintahan berada di tangan rakyat, yang dilakukan dalam suatu mekanisme pemilihan umum untuk memperoleh suara mayoritas rakyat, secara bebas, jujur, adil, dan berkala. Pemerintahan demokratis dengan demikian mengandung tiga pengertian yang harus terkandung di dalamnya, yaitu pemerintahan dari rakyat (government of the people), pemerintahan oleh rakyat (government by the people) dan pemerintahan untuk rakyat (government for the people). Lihat Sudarsono Shobran, Muhammadiyah dan Nahdlatul Ulama dalam Pentas Politik Nasional (Surakarta: Universitas Muhammadiyah Surakarta, 2003), h. 133-134. Terkait dengan respons Islam terhadap demokrasi secara umum ada tiga pandangan: menolak total (total rejection), menerima dengan kritis (critical acceptance), dan menerima sepenuhnya (complete acceptance). Kompatibilitas Islam dengan demokrasi dan demokratisasi dalam pengertian modern tergantung pada identifikasi nilai-nilai universal (hak asasi manusia, kesederajatan dan keterbukaan). Lihat Arskal Salim, "Discourses on Democracy Within Debates on States-Islam Relations in Indonesia," dalam Journal of Indonesian Islam, Vol. 2, No. 01 (June 2008), h. 109. Lihat juga Masdar Hilmy, "Muslim' Approaches to Dempcracy: Islam and Democracy in Contemporary Indonesia," dalam Journal of Indonesian Islam, Vol. 01, No. 01 (June 2007), h. 42. Faktor agama memberikan andil cukup signifikan dalam penerapan demokrasi bagi kehidupan berbangsa dan bernegara. Melalui ormas-ormas Islam moderat, terutama NU dan Muhammadiyah, nilai-nilai agama seperti toleransi, keterbukaan, penghormatan terhadap nilai-nilai kemanusiaan, keadilan dan kesederajatan dapat terjaga dengan baik dan dapat menumbuhkan semangat berdemokrasi di republik ini. Lihat Masdar Hilmy, "Radikalisme Agama dan Politik Demokrasi," dalam MIQOT: Jurnal Ilmuilmu Keislaman, Vol. XXXIX, No. 2 (Juli-Desember 2015), h. 413. 
kemajuan dan kesinambungan pembangunan di daerahnya, bahkan dapat menjadi parameter langsung bagi petahana yang akan maju kembali pada periode kedua, sejauhmana respons dan penerimaan masyarakat terhadapnya. Jika perolehan suaranya lebih rendah dari calon lain, ini pertanda adanya koreksi dari masyarakat terhadap keepemimpinannya pada periode pertama. ${ }^{3}$ Fenomena lain yang muncul adalah terjadinya politisasi ritual agama demi memperoleh dukungan umat, ${ }^{4}$ dan menguatnya dinasti politik di daerah. Meskipun cara seperti itu tidak dapat disalahkan, baik secara aturan (sebelum UU No 8/2015 lahir), dan menurut prinsip-prinsip dan proses demokrasi. ${ }^{5}$ Pilkada serentak tahun 2015 menorehkan beberapa catatan kritis seperti penelitian yang disimpulkan oleh Pangi Syarwi Chaniago. ${ }^{6}$

Pasca Pilkada selalu cenderung diikuti tindakan anarkis atau konflik, dan dalam sebuah penelitian di sebuah kabupaten tertentu, ditemukan bahwa meskipun institusi terkait Pilkada memahami potensi konflik, manajemen konflik yang dipilih adalah metode pembiaran. ${ }^{7}$

${ }^{3}$ Suyatno, "Pemilihan Kepala Daerah (Pilkada) dan Tantangan Demokrasi Lokal di Indonesia," dalam Politik Indonesia, Vol. 1 No. 2 (Juli 2016), h. 232.

${ }^{4}$ Politisasi ritual agama pernah diperankan oleh Partai Keadilan Sejahtera (PKS) pada Pilpres 2009, di mana Presiden PKS ketika itu mengajak Boediono (Cawapres) melalui tim suksesnya untuk melakukan Umrah, hal ini dilakukan untuk menjawab tudingan bahwa Boediono bukan penganut Islam yang taat. Lihat Akh. Muzaki, "Importisasi Ideologi di Politik Islam Indonesia: dari Gerakan Pemikiran hingga ke Partai", makalah pada Seminar Internasional dan Peringatan Dies Natalis Fak. Dakwah dan Komunikasi UIN Sunan Ampel Surabaya, 20 Maret 2014.

${ }^{5}$ Terkait dengan prinsip-prinsip demokrasi, menurut sebuah studi tentang demokrasi di Indonesia tahun 2002, bahwa prinsip-prinsip demokrasi itu dipahami tidak hanya sebagai disposisi yang positif terhadap seperangkat unsur nilai dan prosedur demokrasi, tetapi juga sebagai suatu sikap positif terhadap demokrasi sebagai sebuah gagasan yang tersebar. Pengukuran studi tersebut mencakup sikap positif publik terhadap gagasan bahwa demokrasi adalah bentuk pemerintahan terbaik dibanding yang lain. Hasil survei menunjukkan bahwa umat Islam Indonesia mendukung gagasan demokrasi sebagai bentuk pemerintahan terbaik. Lihat Saiful Mujani, Muslim Demokrat: Islam, Budaya Demokrasi dan Partisipasi Politik di Indonesia Pasca Orde Baru (Jakarta: Gramedia Pustaka Utama, 2007), h. 228.

${ }^{6}$ Penelitiannya menyimpulkan bahwa; (1) pilkada serentak belum efisien; (2) pilkada serentak belum mampu meningkatkan partisipasi politik; (3) pilkada serentak belum mampu menutup celah praktik politik uang; (4) rekruitmen bakal pasangan calon kepala daerah belum terbuka dan transparan; (5) pembiayaan pilkada serentak tidak (tepat) dibebankan ke APBD; (6) MK menolak mengadili sengketa hasil pilkada jika selisih suara lebih dari $2 \%$, melukai rasa keadilan; (7) fenomena munculnya calon tunggal kepala daerah akibat regulasi wajib mundur bagi PNS, TNI/Polri, DPR, DPD, dan DPRD. Lihat Pangi Syarwi Chaniago, "Evaluasi Pilkada Serentak tahun 2015," dalam Politik Indonesia, Vol. 1 No. 2 (Juli 2016), h. 1. Selain itu dalam praktiknya Pilkada langsung juga mempraktikkan drama politik Pilkada dengan mengajukan calon pasangan kepala daerah "boneka" untuk mendampingi satu pasangan calon yang sudah mendaftar, hal ini terjadi setelah masa perpanjangan pendaftaran dari KPU ternyata belum ada juga yang mendaftar, maka dimunculkanlah calon "boneka" ini. Lihat Indaru Setyo Nurprojo, "Bagongan, Pilkada Serentak dan Demokrasi yang Cedera: Belajar dari Purbalingga," dalam Politik Indonesia, Vol. 1, No. 2 (Juli 2016), h. 130.

${ }^{7}$ Fajar Shodiq Ramadhan dan Tri Hendra Wahyudi, "Pembiaran pada Potensi Konflik dan Kontestasi Semu Pemilukada Kota Blitar: Analisis Institusionalisme Pilihan Rasional", dalam Politik Indonesia, Vol. 1, No. 1 (Juli 2016), h. 143. 
Yang lebih tragis adalah pemenang Pilkada akan tampil sebagai sosok pemimpin yang "berkuasa penuh" dan akan membuat perhitungan-perhitungan politik terhadap kawan pendukung dan lawan penentang. Mereka yang masuk katagori lawan politik atau orang yang tidak ikut berkontribusi untuk sebuah kemenangan, siap-siaplah untuk dilengserkan atau dimutasikan ke tempat yang "kering" atau bahkan dinonjobkan.

Pada sisi lain, Pilkada langsung menelan anggaran dana negara yang begitu besar dan terkesan terjadi pemborosan, dan banyak pemimpin yang dilahirkan dari Pilkada tersebut tersangkut korupsi. Bahkan dalam sebuah diskusi publik, tokoh dari perwakilan NU dan Muhammadiyah sudah mencatat bahwa Pilkada langsung itu lebih banyak mudharatnya. ${ }^{8}$

Mencermati berbagai efek negatif dan berbagai pandangan di atas, penelitian ini difokuskan pada respons dan evaluasi kritis dua ormas Islam, NU dan Muhammadiyah Provinsi Jambi, tentang penyelenggaraan Pilkada langsung yang sudah berlangsung selama sepuluh tahun (2005-2015). Penelitian ini menjadi penting untuk melihat bagaimana kedua ormas Islam ini memberikan penilaian dan evaluasi kritis untuk perbaikan Pilkada Langsung ke depan yang lebih bermartabat.

\section{Metode Penelitian}

Penelitian ini menggunakan pendekatan kualitatif deskriptif yang bersumber pada data-data lapangan, dokumentasi, wawancara, atau sumber tertulis yang berupa buku ilmiah, majalah ilmiah, sumber arsip, dokumen pribadi, ataupun artikel. ${ }^{9}$ Sebagai penelitian lapangan (field research), penelitian ini menggunakan teknik pengumpulan data-data di lapangan berupa wawancara dan data dokumentasi, yaitu data-data verbal yang berbentuk laporan penelitian, karya-karya ilmiah, buku dan sebagainya. Dalam pengertian sempit, dokumentasi ini berbentuk tulisan dan dalam arti luas dapat pula berbentuk monumen, artefak, foto, atau hasil rekaman. ${ }^{10}$ Data utama penelitian ini berupa wawancara kepada tokohtokoh elite dari ormas Nahdlatul Ulama dan Muhammmadiyah Provinsi Jambi, dan tokoh pemuda dan mahasiswa yang berafiliasi pada kedua ormas Islam di atas untuk memperkuat hasil penelitian tentang tema yang diteliti ini. Data wawancara dan dokumen lainnya yang diperoleh dalam penelitian ini lebih lanjut dianalisis melalui beberapa teknik analisis,

8"Muhammadiyah dan NU Mencatat Pilkada Langsung Lebih Mudharat", dalam http:// www.republika.co.id, diakses 12 April 2016.

${ }^{9}$ Lexy J. Moleong, Metodologi Penelitian Kualitatif (Bandung: Remaja Rosdakarya, 2000), h. 113.

${ }^{10}$ Lebih jauh tentang makna dokumentasi, lihat Koentjaraningrat, Metode-Metode Penelitian Masyarakat (Jakarta: Gramedia, 1977), h. 63. 
sesuai dengan jenis data yang dikandung, yaitu melalui teknik analisis hermeneutik ${ }^{11}$ dan fenomenologi. ${ }^{12}$

\section{Etika Islam dalam Ranah Politik}

Menurut Franz Magnis Suseno etika, ${ }^{13}$ dibedakan dari ajaran moral. Ajaran moral langsung mengajarkan bagaimana orang harus hidup, berupa rumusan sistematis terhadap anggapan-anggapan tentang apa yang bernilai serta kewajiban-kewajiban manusia. Sedangkan etika merupakan ilmu tentang nilai-nilai ajaran moral, dalam pengertian yang sebenarnya berarti filsafat mengenai bidang moral. Jadi, etika merupakan ilmu bukan sebuah ajaran, tapi refleksi sistematik mengenai pendapat-pendapat, dan istilah-istilah moral. ${ }^{14}$ Jadi, etika merupakan suatu jenjang dari usaha manusia untuk menyesuaikan tindakan-tindakannya dengan aturan yang berlaku.

Melihat hubungan antara etika politik dengan upaya menumbuhkan prinsip moral, maka masalah moral atau akhlak menjadi penting sebagai panduan berpolitik agar para pegiat politik mampu menjadikan dirinya dan partainya bermanfaat bagi kepentingan umat. Tanpa moral atau akhlak yang baik suatu bangsa akan binasa. Sebuah syair dalam bahasa Arab menyatakan: "sesungguhnya bangsa-bangsa itu tegak selama (mereka berpegang pada) akhlaknya. Bila akhlak mereka rusak, maka rusak-binasa pulalah mereka). ${ }^{15}$

Dalam konteks Pilkada ini, tokoh-tokoh Islam sejatinya mengambil peran dan kontribusi untuk memberikan andil dalam pembentukan etika dalam berbangsa dan bernegara. Artinya dalam konteks etika politik Islam, nilai-nilai akhlak yang luas itu menjadi landasan dan pertimbangan dalam melakukan tindakan-tindakan politik dan legitimasi politik. ${ }^{16}$

Islam secara umum memiliki prinsip-prinsip etika berpolitik, sebagaimana tertuang dalam al-Qur'an. Pertama, dalam kaitannya dengan menjaga hubungan antara kepala negara dengan rakyat meliputi kewajiban kepala negara: untuk bermusyawarah dengan warga; menegakkan keadilan; menjaga ketentraman; golongan minoritas memiliki hak yang sama

\footnotetext{
${ }^{11}$ Mark B. Woodhouse, A Preface to Philosophy (California: Wadswoth Publishing Company, 1984), h. 22-23.

${ }^{12}$ Sutopo, Pengantar Penelitian Kualitatif (Surakarta: Pusat Penelitian Universitas Sebelas Maret, t.t.), h. 6.

${ }^{13}$ Dalam bahasa Inggris, etika disebut ethic (singular) yang berarti a sytem of moral principles or rules behavior. Jika kata ethic mendapat tambahan huruf $s$ berarti singular, berarti the branch of philosophy that deals with moral principles (cabang filsafat yang memberikan batasan prinsipprinsip moral). Jika dengan maksud plural (jamak), ethics berarti moral principles that govern or influence a person's behavior. Jonathan Crowther (ed.), Oxford Advanced Learner's Dictionary (London: Oxford University Press, 1955), h. 393.

${ }^{14}$ Franz Magnis Suseno, Filsafat sebagai Ilmu Kritis (Jakarta: Gramedia, 1993), h.31-32.

${ }^{15}$ Ibid, h. 174.

${ }^{16}$ Masykuri Abdillah, Islam dan Dinamika Sosial Politik di Indonesia (Jakarta: Gramedia Pustaka, Utama, 2011), h. 170.
} 
dari segi undang-undang. Kedua, kewajiban rakyat meliputi antara lain taat yang bersyarat; bermusyawarah, menjaga mutu moral dan semangat rakyat. Ketiga, hubungan luar negeri, meliputi hubungan antara negara Islam dengan non-Islam, cinta damai, tanpa paksaan dalam memeluk agama, patuh pada perjanjian yang sudah disepakati, sabar dan mengajak sabar, dan menjaga persaudaraan. ${ }^{17}$

Pada dimensi lain, nilai-nilai civil society harus diperkuat agar tidak menjadi sarana struggle for power dan terkooptasi oleh negara, di tengah munculnya primordialisme baru, seperti nasionalisme etnis, komunalisme, dan sektarianisme agama. Karena itu, sebagai solusi terhadap ancaman civil society, diperlukan upaya pemberdayaannya melalui pendidikan politik dengan memprioritaskan etika Islam berbasis civic values, yaitu keadaban, kemandirian, keswadayaan, keswasembadaan, dan kontrak sosial. ${ }^{18}$

\section{Hasil dan Pembahasan}

\section{Dampak Pelaksanaan Pilkada Langsung bagi Masyarakat}

Respons NU dan Muhammadiyah ini bukan dimaksudkan untuk berpolitik praktis, karena batasan berpolitik telah diatur dalam AD dan ART NU dan Maklumat Kebangsaan Muhammadiyah. Keputusan NU untuk kembali ke Khitah 1926 pada tahun 1983 di Situbundo, dinilai banyak kalangan sebagai langkah yang tepat. NU tidak terikat dengan organisasi politik tertentu dan berbagai kompromi-kompromi politik yang akan menyulitkan perjuangan NU dalam scope jangka panjang, yaitu perjuangan untuk mewujudkan kemaslahatan umat dan negara.

Sementara salah satu pengejawantahan dari kembali ke Khittah adalah bagaimana NU melakukan terobosan-terobosan untuk melakukan pemberdayaan baik di bidang ekonomi, politik, budaya, pendidikan bagi warga Nahdliyin Khususnya dan masyarakat umum. ${ }^{19}$ Patron politik NU itu bukanlah berarti harus meninggalkan politik sama sekali, yang terjadi hanya perubahan paradigma melalui reorientasi terhadap wacana dan praksis politik, sehingga NU dapat menampilkan dirinya secara luwes dalam menyiasati berbagai perubahan dan perkembangan yang terjadi seiring dengan perkembangan dan perubahan zaman. Dengan langkah seperti ini NU bukan organisasi yang apatis dengan politik, namun mampu menjadi wadah yang memiliki peran yang besar dan selalu melihat perkembangan dan dinamika

${ }^{17}$ Ayi Sofyan, Etika Politik Islam (Bandung: Pustaka Setia, 2012), h. 2012, h. 76. Lihat juga, Mhd. Syahnan dan Saleh Partaonan, "The Development of Politico-Religious Sect and its Influence on the Writing of History: The Case of Siffin," dalam Tamaddun, 2002. Lihat juga Abdillah, Islam dan Dinamika Sosial Politik di Indonesia, h.70.

${ }^{18}$ M. Abdul Fattah Santoso, "Kontribusi Etika Islam pada Pendidikan Politik: Solusi bagi Problema Civil Society Indonesia Era Reformasi," dalam PKn Progresif, Vol. 10 No. 1, Juni 2015.

${ }^{19}$ Muhammad AS Hikam, Demokrasi dan Civil Society (Jakarta, LP3ES, 1996) h, 229. 
politik, dan reorientasi ini telah membawa implikasi positif bagi upaya NU untuk memperkuat masyarakat madani (Civil Society).

Sedangkan pada Maklumat Kebangsaan ditegaskan bahwa Muhammadiyah memberikan kebebasan kepada anggota untuk menggunakan hak pilihnya secara cerdas, bijaksana dan pertimbangan rasional dan spiritual dalam memilih pasangan Cakada. Warga Muhammadiyah diberi kebebasan untuk memilih calon kepala daerah, namun bersyarat, yakni harus mempertimbangkan aspek; rasionalitas amanah yang bermakna Muhammadiyah sangat rasional untuk mengambil sikap politik netral, rasional politik kekuasaan; yang bermakna bahwa Muhammadiyah secara kelembagaan tidak berpolitik sesuai dengan Khittah Muhammadiyah, dan rasional kebersamaan cita-cita dan idealisme; yang bermakna bahwa warga Muhammadiyah yang sebagian besar merupakan kaum intelektual yang tergolong pemilih yang cerdas, maka visi dan misi program yang ditawarkan dan berpeluang besar bisa dijalankan oleh masing-masing Cakada. Hal ini menjadi basis pertimbangan utama untuk menentukan ke mana arah suara warga Muhammadiyah. ${ }^{20}$

Terkait dengan Pilkada langsung yang sudah berlangsung di Indonesia sejak 2005, NU dan Muhammadiyah mencermati sudah banyak terjadi konflik dan penyimpangan dalam masyarakat. Salah satu praktik penyimpangan yang cukup marak adalah praktik politik uang, terutama dalam pemilihan pimpinan elite politik. Sedangkan di pihak pemerintah nampak adanya konsensus yang cukup tinggi untuk terus membenahi dan memberdayakan lembaga-lembaga penting demokrasi pada semua tingkat, meskipun tetap menghadapi hambatan berupa masih lemahnya kepatuhan pada peraturan perundang-undangan dan nilai-nilai positif yang dianut masyarakat.

Berkenaan dengan hubungan kelembagaan pusat dan daerah, masalah yang muncul adalah bahwa pelaksanaan otonomi daerah menghadapi kendala yang diakibatkan oleh distorsi dan inkonsistensi peraturan perundangan serta masih belum dapat menghilangkan dampak buruk dari sentralisasi kekuasaan, padahal konsolidasi demokrasi mensyaratkan pentingnya persatuan nasional. Stabilitas politik sangat diperlukan untuk menjaga konsolidasi demokrasi. Persatuan nasional perlu didasarkan pada aspek keanekaragaman, desentralisasi dan keadilan sosial.

Akan tetapi pelaksanaan Pilkada langsung tampaknya memberikan dampak buruk di masyarakat, bahkan munculnya penguatan otonomi daerah yang eksesnya adalah melemahnya kepatuhan pada pemimpin daerah yang lebih tinggi, seperti kepatuhan Bupati/Walikota kepada Gubernurnya. Hal ini seperti diungkapkan oleh H.M. Iskandar Nasution, Sekretaris Umum NU Provinsi Jambi;

Dampak negatif yang kami cermati dari Pilkada langsung adalah kurangnya kepatuhan seorang Bupati/Walikota pada gubernurnya, undangan gubernur kepada Bupati/Walikota

${ }^{20}$ Wawancara dengan Sekretaris Umum PW Muahammadiyah Provinsi Jambi, Agus Salim, tanggal 17 September 2016. 
seringkali dengan mudahnya tidak dihadiri. Ini akan mengganggu komunikasi politik dan birokrasi antara pemerintah kabupaten/kota dengan pemerintah provinsi Jambi, yang berpotensi menjadi penghambat lancarnya pembangunan. Berbeda dengan Gubernur pada pemerintah pusat, ikatan birokrasinya masih kuat. Jika ada yang perlu ditinjau ulang atau dikembalikan ke DPR/DPRD, maka menurut saya, cukup pemilihan Bupati dan Walikota Saja, sedangkan Presiden/Wakil Presiden, dan Gubernur/Wakil Gubernur tetap dipertahankan Pilkada langsung. ${ }^{21}$

Wawancara di atas menunjukkan bahwa penguatan otonomi daerah dan Pilkada langsung telah menempatkan pejabat Bupati/Walikota menjadi penguasa daerah yang seolah terlepas dari birokrasi pemerintah provinsi dan pusat. Ini terjadi karena mereka dipilih secara langsung oleh rakyat, sehingga kedaulatan berada pada rakyat, yang disimbolkan oleh pemeritah kabupaten/kota, pada wilayah ini seringkali potensi disharmonisasi pemerintah provinsi dan kabupaten/kota seringkali muncul, yang tentu saja mengganggu jalannya roda pemerintahan dan percepatan pembangunan di daerah.

Selain itu, mobilisasi massa melalui penggunaan politik uang (money politics) akan menjadi faktor pemicu konflik di dalam pelaksanaan Pilkada. Padahal penggunaan politik uang bukan hanya merupakan perbuatan pidana, tapi juga mendistorsi dan melanggar nilai-nilai agama, yang jika dibiarkan, maka praktik-praktik itu akan menjadi kebiasaan yang seolah menjadi hal yang lumrah dan maklum setiap ada moment Pemilihan. Pada satu sisi Pilkada memberikan warna demokrasi, akan tetapi pada sisi lain memunculkan sejumlah ironi. Ironi karena terjadi polarisasi antar kelompok masyarakat dan renggangnya hubungan interaksi sosial dan silaturahmi menjadi salah satu dampak nyata dan tidak dapat dikesampingkan sebagai ekses Pilkada, misalnya konflik yang muncul pada pemilihan Gubernur Jambi Periode 2016-2021, terjadi kerenggangan hubungan (disharmonis) antara seorang calon Gubernur dengan pamannya sendiri karena sang paman adalah pendukung utama calon gubernur lain, antara tetangga tidak berteguran karena berbeda pilihan.

Pilkada dalam konteks di atas bukan lagi menjadi pesta rakyat, tapi pada senyatanya adalah pesta parpol dan pemenang Pilkada, sehingga Pilkada tidak lebih sebagai prosesi pergantian aktor pejabat yang diwarnai dengan berbagai konflik, kecurangan, penghalalan segala cara, dengan tidak mengindahkan nilai agama dan moral hingga intimidasi terhadap kandidat. Pada tahap inilah Pilkada langsung menjadi ajang yang tidak lagi menjadi menarik karena berbagai kecurangan dan kemudaratan berlangsung, dan seolah terjadi pembiaran oleh pemerintah dan tokoh-tokoh masyarakat, karena dianggap bahwa itu adalah bagian dari politik, seolah politik boleh melakukan apa saja asal tujuan tercapai, seperti diungkapkan oleh Nasroen Yasier, Wakil Ketua PW Muhammadiyah Provinsi Jambi:

Muhammadiyah melihat bahwa Pilkada langsung telah menimbulkan banyak ekses

${ }^{21}$ Wawancara dengan H.M Iskandar Nasution, Sekretaris Umum PWNU Provinsi Jambi, 16 September 2016 di Jambi. 
negatif seperti terjadinya pengelompokan/firqah-firqah dalam masyarakat, memudarnya suasana ukhuwah, silaturahmi dan kekeluargaan sesama umat bahkan sesama keluarga hanya karena perbedaan pilihan calon. Hal ini tentu saja bertentangan dengan nilainilai dan etika politik Islam yang menganjurkan persatuan umat, menjaga ukhuwah dan silaturahmi. Jadi, tampaknya lebih banyak mudaratnya ketimbang manfaatnya. Selain itu calon yang menang akan menunjukkan euphorianya bersama dengan tim sukses dan pendukungnya, sementara tim calon yang kalah akan tersingkir, dan di sisi lain mereka yang kalah kerapkali juga beserta pendukungnya berusaha mencari celah untuk menggugat atau mencari-cari kesalahan yang menang, dan biasanya calon yang kalah di daerah akan sulit menenangkan konstituennya. Ormas Islam juga terbawa arus dalam dukung mendukung meski sudah ada larangan, dan ada organisasi-organisasi kecil dan dadakan yang membentuk kelompok pendukung calon, yang ujung ujungnya adalah untuk menumpang dan menikmati fasilitas apabila calon yang didukung menang. Inilah efek negatif yang ikut berkontribusi merusak mental masyarakat. ${ }^{22}$

Apa yang diungkapan di atas adalah realitas dari Pilkada langsung yang justru akan menurunkan atau merusak mental masyarakat. Selain itu masyarakat Islam seolah ikut terkontaminasi oleh praktik-praktik kecurangan dalam Pilkada, yang dianggap sudah hal yang lumrah. Padahal praktik-praktik itu bertentangan dengan nilai-nilai agama. Pada masyarakat akan tumbuh subur sikap pragmatisme yang tinggi. Artinya, apa yang dilakukan adalah semata-mata untuk mengejar keuntungan atau fasilitas yang bersifat instan dan jangka pendek. Mereka tidak lagi tertarik untuk berpikir idealis dan berjuang untuk mewujudkannya, serta bersabar menunggu proses hingga pada waktunya mereka akan menikmati perjuangannya.

Ungkapan senada yang menilai banyaknya dampak negatif dari Pilkada langsung, seperti besarnya cost yang dikeluarkan, maraknya politik uang dan tumbuh suburnya kemunafikan dalam masyarakat seperti diungkapkan oleh H. M Aminullah Amit, Ketua PWNU Provinsi Jambi:

Pilkada langsung itu selain memang banyak sisi positifnya, tapi juga banyak sisi negatif atau dampak buruknya bagi masyarakat, seperti cost pemilihan seorang kepala daerah terlalu besar, baik dari cost yang dikeluarkan oleh pemerintah maupun yang dikeluarkan oleh calon. Selain itu merebaknya politik uang di masyarakat, jika diadakan oleh DPRD tetap ada permaian uang, tetapi tidak melibatkan masyarakat, setidaknya mengecilkan mudharat. Menurut saya yang paling merusak adalah suburnya kemunafikan di masyarakat, karena masyarakat sudah pintar bermain uang, mereka menerima uang dari calon yang beramanat supaya memilih dia dalam pemilihan, tetapi mereka justru tidak memilih atau kalau memilih, dia memilih calon lain. ${ }^{23}$ 2016.

${ }^{22}$ Wawancara dengan Nasroel Nasir, Wakil Ketua PW Muahammadiyah, tanggal 16 September

${ }^{23}$ Wawancara dengan Ketua PWNU Provinsi Jambi, H. Aminullah Amit, tanggal 14 September 2016 di Jambi. 
Mencermati berbagai dampak negatif dari Pilkada langsung di atas, menunjukkan bahwa pesta demokrasi yang seharusnya menjadi pesta rakyat untuk memilih pemimpinnya sendiri secara langsung, kerapkali dimanfaatkan oleh orang-orang yang tidak mempedulikan aturan-aturan Pilkada yang sudah ditetapkan, tidak memperhatikan nilai-nilai agama dan moral yang berlaku di masyarakat dan mereka berjuang untuk merebut pemerintahan atau kekuasaan hanya bermuara untuk kepentingan jangka pendek, yaitu merebut kekuasaan dan membagi bagikan "kue-kue" kekuasaan itu untuk dinikmati bersama pada mereka yang ikut berjuang untuk memenangkan pertarungan Pilkada itu. Jika ini terus menjadi paradigma masyarakat, maka harapan masyarakat untuk memunculkan pemimpin yang memiliki good governance, dan melakukan percepatan pembangunan sulit untuk terwujud, justru yang muncul adalah maraknya korupsi selain untuk mengembalikan modal mereka, tapi juga memperkaya diri.

\section{Tinjauan dan Evaluasi Kritis Nahdlatul Ulama dan Muhammadiyah}

Merespons tentang dampak yang ditimbulkan dari pelaksanaan Pilkada langsung itu, maka kedua ormas Islam di Provinsi Jambi ini memberikan beberapa catatan kritis untuk meminimalisir dampak yang ditimbulkan dari Pilkada langsung tersebut. Kalangan NU melihat bahwa Pilkada langsung masih dimungkinkan untuk dilanjutkan, namun diperlukan perbaikan-perbaikan dari sistem yang sedang berlangsung, agar pesta demokrasi rakyat itu bukan hanya dilalui begitu saja tanpa mempedulikan nilai-nilai moral dan agama yang berlaku di masyarakat. Kalau nilai-nilai moral dan agama dikesampingkan dengan prinsip "menghalalkan segala cara agar tujuan tercapai", maka Pilkada langsung yang bertujuan untuk melibatkan langsung masyarakat pada prosesi pemilihan pemimpinnya, hanya dinikmati oleh segelintir orang yang memiliki modal dan ketenaran, sedangkan harapan untuk kesinambungan dan percepatan pembangunan untuk mewujudkan kesejahteraan rakyat akan menjadi harapan yang sulit diwujudkan. Seperti terungkap dalam wawancara dengan Ketua PWNU Jambi:

Saya pada prinsipnya masih mendukung Pilkada langsung, namun dengan beberapa catatan yang harus diperbaiki; yaitu adanya aturan yang lebih ketat tentang larangan politik uang, ada perbaikan-perbaikan pada aspek yang berpotensi merusak akhlak masyarakat, seperti masyarakat dilarang menerima uang dari siapa pun calonnya. Parpol dilarang menerima uang mahar dari calon, karena jika ini tetap diberlakukan, maka hanya yang bermodal besar dan memiliki ketenaran yang mampu maju di Pilkada, dan bisa saja calon yang maju hanya mengandalkan uang dan ketenaran itu, sementara dari aspek ilmu dan pengalaman memimpin masih minim. Selain itu uang mahar akan menjadikan calon yang terpilih nanti berniat kuat untuk segera mengembalikan uangnya, dan di sinilah seringkali calon terpilih mengambil uang dari negara dengan cara yang tidak halal alias korupsi. ${ }^{24}$

\footnotetext{
${ }^{24}$ Wawancara ketua PWNU Jambi, 13 September 2016di Jambi
} 
Berbeda dengan Nasroen Yasir, Wakil Ketua PW Muhammadiyah dan Koordinator bidang Hikmah dan Kebijakan Publik, mengatakan:

Melihat banyaknya mudarat yang ditimbulkan dari Pilkada langsung, maka pemerintah harus meninjau kembali sistem pemilihan Pilkada lansung ini dengan mengevaluasi berbagai ketimpangan-ketimpangan yang terjadi terutama yang terkait dengan pelanggaran norma-norma agama dan sosial. Jika sistem Pilkada langsung ini tetap dipertahankan, maka kita harus mengadvokasi masyarakat, agar tidak terjerumus pada perilaku-perilaku yang bertentangan dengan nilai nilai Islam dan moral yang ada. Jika kita ingin merubah sistem itu, maka regulasinya harus dirubah, dan itu adalah PR nya DPR. Jadi sebagai ormas Islam perlu ikut mengawal agar sistem ini berjalan dan lebih banyak manfaat daripada mudharatnya, dan bukan sebaliknya. ${ }^{25}$

Apa yang terungkap dari wawancara di atas menegaskan bahwa mekanisme Pilkada langsung harus selalu dievaluasi dan diberikan perbaikan-perbaikan sistem itu, agar memberikan manfaat bagi masyarakat dan bukannya menimbulkan berbagai ekses negatif. Sistem dan mekanisme itu perlu terus diperbaiki dan disempurnakan serta dievaluasi karena masih banyak sisi kelemahan, yang seringkali kontra produktif bagi proses berjalannya demokratisasi. Kelemahan-kelemahan di atas seringkali menjadi pemicu dan akar persoalan konflik sosial dan politik di masyarakat. Akan tetapi sumber konflik ini sesungguhnya tidak hanya pada tataran normatif yaitu perundang-undangan, tetapi juga dalam konteks implementasinya yang seringkali tidak konsisten dan menyimpang dari tujuan dasarnya.

Beberapa deviasi dan distorsi dalam praktik penyelenggaraan Pilkada yang masih menjadi ganjalan dan banyak dipertanyakan oleh masyarakat adalah masih banyaknya warga yang mempunyai hak pilih tetapi tidak tercatat sebagai pemilih tetap. Persoalan lain adalah terjadinya distorsi dan deviasi dalam memilih pemimpin terbaik. Melalui Pilkada yang terpilih disinyalir justru bukan putra terbaik yang dimiliki daerah. Meskipun banyak menghasilkan hal positif dan mampu menjaring kader daerah yang baik dan kompeten, namun tidak sedikit yang meleset jauh dari harapan pemilih.

Berbagai ekses negatif yang timbul dari Pilkada langsung tidak serta merta kalangan tokoh ormas Islam menyetujui agar Pilkada langsung itu dikembalikan kepada DPRD, mereka tetap mendukung Pelaksanaan Pilkada langsung, karena Pilkada langsung adalah proses pembelajaran bagi masyarkat untuk memilih langsung pemimpinnya, sehingga ketika calon pemimpin yang dipilihnya menang, maka mereka akan mendukung dan menjalankan program secara bersama secara sukarela dengan pemerintah yang terpilih, dan jika pemimpin yang dipilih memiliki kesalahan dalam memimpin, maka mereka juga yang akan memberikan nasehat dan peringatan, hal ini seperi terungkap dari wawancara dengan Agus Salim, Sekretaris Umum PW Muhammadiyah Provinsi Jambi:

\footnotetext{
${ }^{25}$ Wawancara dengan Nasroel Nasir, Wakil Ketua PW Muahammadiyah, tanggal 16 September 2016.
} 
Muhammadiyah tetap mendukung terlaksananya Pilkada langsung sebagai bagian dari proses pembelajaran demokrasi bagi rakyat untuk memilih kepala daerahnya sendiri, agar benar-benar mencerminkan kehidupan demokrasi, dengan catatan. Pertama, masyarakat menggunakan hak pilihnya secara aktif, cerdas, bertanggung jawab, mandiri dan tidak terpengaruh pada politik uang, menjaga kerukunan dan persaudaraan serta menghormati perbedaan pilihan. Kedua, penyelenggara Pilkada harus menjamin pelaksanaan Pilkada tepat waktu, aman, dan lancar, bertindak netral, objektif, adil transparan dan independen. Ketiga, aparatur keamanan dan pemerintah daerah harus menjaga netralitas, keamanan dan ketertiban. Keempat, para calon Kepala daerah harus bersaing secara sehat, tidak melakukan politik uang, tidak memaksakan kehendak, tidak memecah belah persatuan dan persaudaraan umat serta bersikap kesatria yaitu siap menang dan kalah. ${ }^{26}$

Hal senada disampaikan oleh Ramazani Novanda, Ketua PMII cabang Jambi:

Pilkada langsung, rakyat dapat memilih langsung kepala daerahnya sesuai dengan penilaian pribadinya. Idealnya semua kebijakan negara ditentukan oleh suara rakyatnya. Masyarakat dapat bebas memilih sesuai dengan track record dan dengan penilaian yang secara bebas karena suara rakyat adalah suara Tuhan. Kemudian rakyat bisa berperan langsung ikut serta dalam proses pemilihan, sehingga pemimpin pun lahir murni, dan masyarakat merasa dilibatkan secara langsung. Karena itu menurut saya Pilkada langsung masih relevan dan mesti dipertahankan, apalagi memperjuangkan terwujudnya Pilkada langsung ini cukup lama, hanya perlu pengawalan dalam memperbaiki berbagai kecurangan yang terjadi setiap kali Pilkada. Inilah tugas kita, tugas kami sebagai pemuda. ${ }^{27}$

Persoalan lain yang menjadi kekhawatiran dari Pilkada langsung adalah konsentrasi masyarakat menjadi buyar, karena diperhadapkan dengan hiruk pikuk politik yang tidak pernah berhenti. Bahkan ada kekhawatiran banyak pihak bahwa agenda politik nasional tidak memberikan kontribusi bagi pembangunan kesejahteraan masyarakat, dan harus diakui bahwa saat ini pemerintah masih pada tataran konsolidasi penataan infrastruktur politik, baik ditingkat pusat maupun daerah dan belum menunjukkan prestasi yang baik bagi penataan pembangunan ekonomi nasional.

Karena itu lagi-lagi yang menjadi sorotan adalah sistem dan mekanisme ini yang perlu terus disempurnakan, dan dievaluasi karena masih banyak sisi kelemahan yang seringkali kontra produktif bagi proses demokratisasi. Kelemahan-kelemahan di atas seringkali menjadi pemicu dan akar persoalan konflik sosial dan politik di masyarakat.

Dalam skala yang bersifat nasional, Pemilu Presiden melahirkan ancaman politik yang intensitasnya lebih rendah dibandingkan Pilkada yang bersifat lokal. Akibatnya konflik dalam Pemilu Presiden tidak terlampau nampak di hadapan masyarakat, karena isu-isu

\footnotetext{
${ }^{26}$ Wawancara dengan Agus Salim, Sekretaris Umum PW Muhammadiyah Provinsi Jambi, 15 September 2016 di Jambi.

${ }^{27}$ Wawancara dengan Ramazani Novanda, Ketua PMII cabang Jambi, tanggal 17 September 2016.
} 
yang ditawarkan tidak bersinggungan langsung dengan kepentingan masyarakat setempat. Namun, konflik dalam Pilkada sangat erat dengan isu dan persoalan yang dibicarakan masyarakat.

Kenyataan di beberapa wilayah yang telah menyelenggarakan Pilkada tidak melahirkan legitimasi. Hal ini terjadi karena tingginya angka Golput, bahkan di beberapa daerah Golput memenangkan Pilkada. Berbagai persoalan yang mengitari Pilkada itu, maka peran dewan kehormatan Pilkada harus senantiasa mengevaluasi dan melakukan perbaikan-perbaikan pada setiap pelaksanaan Pilkada agar Pilkada ini menyenangkan masyarakat dan bukannya membebani bahkan merusak masyarakat, seperti diungkapan oleh Imam Syafii, Ketua Ikatan Mahasiswa Muhammadiyah Provinsi Jambi:

Pada prinsipnya saya tetap mendukung Pilkada langsung. Yang harus diperbaiki dalam Pilkada langsung adalah bahwa Cakada dan Parpol dari awal harus jujur, transparan dana yang digunakan dalam kampanyenya, asset yang dimiliki, tidak melibatkan pemodal, sehingga tidak melahirkan potensi koruspsi dan sportif dalam pemilihan. Sedangkan KPU dan Bawaslu harus bekerja sesuai dengan tupoksinya, tidak boleh berpihak. Jadi, dalam pelaksanaan Pilkada perlu advokasi, jangan sampe masyarakat dimanfaatkan oleh oknum-oknum yang ingin memanfaatkan keluguan masyarakat.Penyelenggara Pemilu harus berusaha untuk mengurangi Golput, meminimalisir pelanggaran Pilkada. Kita harus ikut memberikan pemahaman kepada masyarakat tentang demokrasi dan sitem Pilkada langsung agar mereka tidak menjadi objek politik sesaat oleh oknumoknum yang memanfaatkan mereka demi mencapai puncak kekuasaan semata. ${ }^{28}$

Memperhatikan pandangan tokoh-tokoh ormas Islam di atas, tampak bahwa NU dan Muhammadiyah sama-sama sepakat mengatakan bahwa dampak dari Pilkada langsung telah menimbulkan ekses-ekses negatif dan buruk bagi masyarakat, seperti maraknya politik uang, terjadinya konflik dan kekerasan, terusiknya suasana kekeluargaan dan silaturahmi, melambatnya pembangunan karena konsentrasi politik yang lebih kuat, tumbuh suburnya kemunafikan dalam masyarakat, apatisme masyarakat dalam bentuk Golput, dan menguatnya korupsi di kalangan pejabat karena mereka bermaksud mengembalikan uang yang sudah dikeluarkan ketika akan bertarung mendapatkan jabatan atau persiapan untuk maju lagi pada Pilkada berikutnya. Selain itu merebaknya kampanye hitam (black campaign), yang bersumber pada rumor, gossip, bahkan menjurus sejumlah teknik pro-paganda. ${ }^{29}$ Praktikpraktik seperti ini bukan hanya menciderai semangat berdemokrasi, di mana rakyat sebagai panglima, tetapi juga menodai dan merusak nilai-nilai agama yang sejatinya selalu diamalkan dengan baik dan dijaga kesuciannya oleh umat.

Berbagai pelanggaran terhadap tatanan sosial, agama dan moral, tampak diabaikan

\footnotetext{
${ }^{28}$ Wawancara dengan Imam Syafii, Ketua Ikatan Mahasiswa Muhammadiyah Provinsi Jambi tanggal 17 September 2016.

${ }^{29}$ Anis Hidayati, "Kampanye Pemilihan Umum Presiden dan Wakil Presiden Perspektif Fikih Siyasah," dalam al-Daulah, Vol. 05, No. 01 (April 2015), h.29.
} 
oleh masyarakat, padahal mereka umumnya adalah umat beragama yang taat menjalankan agamanya, namun dengan mudah melanggar norma agama dan moral yang sudah dipraktikkan lama di masyarakat sebagai nilai nilai luhur dan spiritual. Masyarakat seolah sudah terkontaminasi dengan sifat pragmatisme yang hanya mementingkan kepentingan jangka pendek dan melupakan kepentingan umat jangka panjang.

\section{Penutup}

Ormas NU dan Muhammadiyah sama-sama menegaskan bahwa dampak dari Pilkada langsung telah menimbulkan ekses-ekses negatif yang mengikis nilai-nilai moral masyarakat, seperti maraknya politik uang, baik politik uang antara calon kepala daerah dengan partai pengusung, maupun politik uang antara calon dengan masyarakat pemilih. Terjadinya konflik dan keretakan hubungan masyarakat, bahkan sesama keluarga karena berbeda, melambatnya pembangunan karena tokoh-tokoh politik dan pejabat pemerintah lebih konsen mengurus agenda politik ketimbang agenda pembangunan, tumbuh suburnya kemunafikan dalam masyarakat karena menganggap bahwa berpolitik itu identik dengan "apa yang dijanjikan tidak selalu mesti diwujudkan", apatisme masyarakat dalam bentuk golput karena menganggap bahwa Pemilu hanya menggantikan periode, tapi tidak mampu melahirkan perubahan dan kesejahteraan bagi mereka, dan menguatnya korupsi di kalangan pejabat karena mereka bermaksud mengembalikan uang yang sudah dikeluarkan ketika akan bertarung mendapatkan jabatan atau untuk persiapan untuk maju lagi pada Pilkada berikutnya.

Jika dilihat dari dampak yang ditimbulkan dari pelaksananaan Pilkada langsung di atas, maka NU dan Muhammadiyah memberikan tinjauan kritis dan rekomendasi untuk mendapat perhatian pada Pilkada yang akan datang, yang dapat dirinci sebagai berikut. Pertama, penyelenggara Pilkada, baik KPU maupun Panwas harus menjaga independensi, objektif, amanah, adil, tranparan dan memastikan bahwa semua masyarakat yang memenuhi syarat mendapatkan kartu pemilih. Kedua, masyarakat pemilih harus menggunakan hak pilihnya secara bertanggung jawab dan menghindari money politic, menjaga persaudaraan dan menhormati perbedaan pilihan. Ketiga, memberikan advokasi kepada masyarakat agar terbebas dari praktik-praktik penyimpangan dari pelaksanaan Pilkada. Keempat, calon kepala daerah harus bersaing secara sehat, tidak melakukan politik uang, tidak memecah belah persatuan umat dan bersikap ksatria yaitu siap kalah dan menang. Kelima, semua pihak dapat menghindari adanya black campaign, dan pembunuhan karakter pada pihak pesaing. Keenam, semua pihak harus mengikuti aturan-aturan Pilkada secara konsisten dan senantiasa menempatkan nilai-nilai agama dan moral masyarakat menjadi pedoman dan penuntun.

\section{Pustaka Acuan}

Abdillah, Masykuri. Islam dan Dinamika Sosial Politik di Indonesia. Jakarta: Gramedia Pustaka, Utama, 2011. 
Asy’arie, Musa. Filsafat Islam Sunah Nabi dalam Berpikir. Yogyakarta: LESFI, 1999.

Chaniago, Pangi Syarwi. "Evaluasi Pilkada Serentak tahun 2015," dalam Politik Indonesia, Vol. 1 No. 2, 2016.

Crowther, Jonathan (ed.). Oxford Advanced Learner's Dictionary. London: Oxford University Press, 1955.

Fitriyah. "Meninjau Ulang Sistem Pilkada Langsung: Masukan Untuk PILKADA Langsung Berkualitas," dalam Ilmu Politik, Vol. 2, No. 1, 2011.

Hidayati, Anis. "Kampanye Pemilihan Umum Presiden dan Wakil Presiden Perspektif Fikih Siyasah," dalam al-Daulah, Vol. 05, No. 1, 2015.

Hikam, Muhammad AS. Demokrasi dan Civil Society. Jakarta: LP3ES, 1996.

Hilmy, Masdar. "Muslim' Approaches to Democracy: Islam and Democracy in Contemporary Indonesia," dalam Journal of Indonesian Islam, Vol 01, No. 01, 2007.

Hilmy, Masdar. "Radikalisme Agama dan Politik Demokrasi," dalam MIQOT: Jurnal Ilmuilmu Keislaman, Vol. XXXIX, No. 2, 2015.

Jones, Sidney. Sisi Gelap Demokrasi, Kekerasan Masyarakat Madani di Indonesia. Jakarta: Paramadina, 2015.

Koentjaraningrat. Metode-Metode Penelitian Masyarakat. Jakarta: Gramedia, 1977.

Martin, Ali. "Quo Vadis Transisi Demokrasi: Arah Demokratisasi Indonesia di tengah Demokrasi Pasar," dalam Spektrum, Vol. 7, No. 1, 2010.

Misrawi, Zuhairi. Hadratussyakh Hasym As'ary: Moderasi, Keumatan dan Kebangsaan. Jakarta: Kompas, 2010.

Moleong, Lexy J. Metodologi Penelitian Kualitatif. Bandung: Remaja Rosdakarya, 2000.

Mujani, Saiful. Muslim Demokrat: Islam, Budaya Demokrasi, dan Partisipasi Politik di Indonesia Pasca Orde Baru. Jakarta: Gramedia Pustaka Utama, 2007.

Muzaki, Akh. "Importisasi Ideologi di Politik Islam Indonesia: dari Gerakan Pemikiran hingga ke Partai," makalah pada Seminar Internasional dan Peringatan Dies Natalis Fak Dakwah dan Komunikasi UIN Sunan Ampel Surabaya, 20 Maret 2014.

Nazir, Moh. Metode-metode Penelitian Masyarakat. Jakarta: Gramedia, 1997.

Nurprojo, Indaru Setyo. "Bagongan, Pilkada Serentak dan Demokrasi yang Cedera: Belajar dari Purbalingga," dalam Politik Indonesia, Vol. 1, No.2, 2016.

Ramadhan, Fajar Shodiq dan Tri Hendra Wahyudi. "Pembiaran pada Potensi Konflik dan Kontestasi Semu Pemilukada Kota Blitar: Analisis Institusionalisme Pilihan Rasional," dalam Politik Indonesia, Vol.1 No. 1, 2016.

Salim, Arskal. "Discourses on Democracy within Debates on States-Islam Relations in Indonesia," dalam Journal of Indonesian Islam, Vol. 2 No. 01, 2008.

Shobran, Sudarsono. Muhammadiyah dan Nahdlatul Ulama dalam Pentas Politik Nasional. Surakarta: Universitas Muhammadiyah Surakarta, 2003. 
MIQOT Vol. XLI No. 1 Januari-Juni 2017

Sinaga, Rudi Salam. "Implikasi Distorsi Demokrasi Pada Pemilukada terhadap Penguatan Demokrasi Lokal,” dalam Perspektif, Vol. 5, No. 12012.

Sofyan, Ayi. Etika Politik Islam. Bandung: Pustaka Setia, 2012.

Suseno, Franz Magnis. Filsafat Sebagai Ilmu Kritis. Jakrta: Gramedia, 1993.

Sutopo. Pengantar Penelitian Kualitatif. Surakarta: Pusat Penelitian Universitas Sebelas Maret, t.t.

Syahnan, Mhd. dan Saleh Partaonan, "The Development of Politico-Religious Sect and its Influence on the Writing of History: The Case of Siffin," dalam Tamaddun, 2002.

Suyatno. "Pemilihan Kepala Daerah (Pilkada) dan Tantangan Demokrasi Lokal di Indonesia," dalam Politik Indonesia, Vol. 1, No. 2, 2016.

Woodhouse, Mark B. A Preface to Philosophy. California: Wadswoth Publishing Company, 1984.

\section{Wawancara}

Wawancara dengan Sekretaris Umum PW Muhammadiyah Provinsi Jambi, Agus Salim, tanggal 17 September 2016 di Jambi.

Wawancara dengan H.M Iskandar Nasution, Sekretaris Umum PWNU Provinsi Jambi, 16 September 2016 di Jambi.

Wawancara dengan Nasroel Nasir, Wakil Ketua PW Muhammadiyah, tanggal 16 September 2016.

Wawancara dengan Ketua PWNU Provinsi Jambi, H. Aminullah Amit, tanggal 14 September 2016 di Jambi.

Wawancara dengan Ramazani Novanda, S.Pd.I, ketua PMII cabang Jambi, tanggal 17 September 2016

Wawancara dengan Imam Syafii, ketua Ikatan Mahasiswa Muhammadiyah Provinsi Jambi tanggal 17 September 2016. 